症例

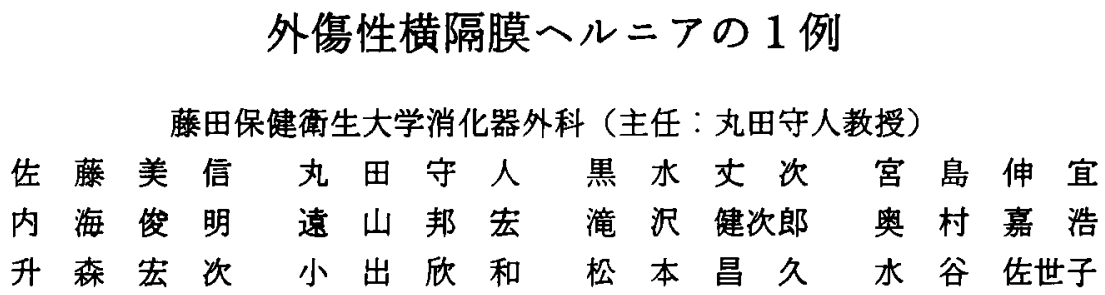

交通事故による外傷性横隔膜ヘルニフの1 例を释験したので，1981年 1 月より1990年 11月までの本邦報告267例の集計とともに文献的考察を加え報告する。症例は31歳, 男性 で交通事故にて受傷し腰痛を主訴に来院した。来院時の胸部単純 X 線写真において左横 隔膜の挙上を認めたため, 超音波検查, CT を施行し外傷性左横隔膜へルニアと確診し た. 経腹的に緊急手術を施行し, 脱出葴器である胃, 大網を腹腔内に戻し, 横隔膜を縫 合閉鎖し手術を終了した。患者は第39病日目に軽快退院した。

今回の集計を従来の報告(1ー)と比較検討した。発生部位では右側例は左側例に比し稀 と言われていたか，近年ではその差は縮小㑯向にあった。 また，受傷機転では交通事故 によるものの增加を認めた，今回の集計で死亡例は203例中20例（9.8\%）であったか， これは従来までの報告と差を認めなかった。

索引用語：外傷性横隔膜へルニア

はじめに

外临性横隔膜へルニアは，従来比較的稀な疾患とさ れてきた。しかし，近年交通事故や労倒災害の増加に 伴いその報告例も増加している。したがって胸腹部外 侮患者の診療に際し，常に本疾患の存在を念頭におく 必要がある，今回著者らは，交通事故による外傷性横 隔膜ヘルニフの 1 例を経験したので，最近10年間の本 邦報告267例とともに若干の考察を加え報告する.

\section{症例}

患者：31歳, 男性.

主訴: 腰痛.

家族歴：特記すべき事なし。

既往歴：昭和57年，25歳時，脳動静脈奇形で他院に て手術を施行した。昭和59年，27歳時，十二指腸潰瘍 で保存的内服治療をうけた。

現病歴：平成元年 7 月20日，夜間道路横断中に左方 からの乗用車と衝突した，頭部，腰部を打撲し救急車 にて来院した。

入院時現症：体格，栄盖中等度. 意識清明。血王139/ $72 \mathrm{mmHg}$, 脈拍数 $88 /$ 分, 眼瞼結膜に負血なし. 眼球結

1993年 6 月 4 日受付 1994年 1 月31日採用
膜に黄瘨なし、腰痛を訴えたが，呼吸は規則的で胸痛， 呼吸困難は認めなかった。呼吸音は右肺は正常だか， 左肺で减弱していた。腹部は平坦，軟で圧痛等を認め なかった。

入院時検查成績：Table 1 に示す如く末梢血では軽

Table 1 Laboratory data on admission

\begin{tabular}{|c|c|c|c|}
\hline พвC & $9800 / \mu 1$ & PH & 1.416 \\
\hline RBC & 357 万/ $\mu 1$ & $\mathrm{PCO}_{2}$ & $33.0 \mathrm{mmHg}$ \\
\hline Hb & $11.8 \mathrm{~g} / \mathrm{dl}$ & $\mathrm{PO}_{2}$ & $66.6 \mathrm{mmHr}$ \\
\hline Het & $35.9 \%$ & $\mathrm{HCO}_{3}^{-}$ & $21.2 \mathrm{mmol} / \mathrm{L}$ \\
\hline \multirow[t]{2}{*}{ PLT } & 22 万 $/ \mu$ & BE & $-1.8 \mathrm{mmol} / \mathrm{L}$ \\
\hline & & $\mathbf{0}_{2}$ Sat. & $93.6 \%$ \\
\hline I.P & $5.6 \mathrm{~g} / \mathrm{dl}$ & BUN & $9 \mathrm{mg} / \mathrm{dl}$ \\
\hline Alb & $3.3 \mathrm{~g} / \mathrm{dl}$ & Amy. & $100 \mathrm{U}$ \\
\hline T.B & $0.6 \mathrm{mg} / \mathrm{dl}$ & $60 T$ & $55 \mathrm{mU} / \mathrm{ml}$ \\
\hline $\mathrm{Na}$ & $134 \mathrm{mEq} / \mathrm{l}$ & GPI & $25 \mathrm{mU} / \mathrm{ml}$ \\
\hline$K$ & $3.3 \mathrm{mEq} / \mathrm{l}$ & CRN & $0.6 \mathrm{mg} / \mathrm{dl}$ \\
\hline CI & $104 \mathrm{mEq} / \mathrm{l}$ & B.S & $91 \mathrm{mg} / \mathrm{dl}$ \\
\hline
\end{tabular}


度の貧血を，生化学検查では軽度の低蛋白血症と肝機 能障害を認めた。血液ガス分析では $\mathrm{PO}_{2} 66.6 \mathrm{mmHg}$, $\mathrm{O}_{2}$ Sat. $93.6 \%$ と低値を示した。心電図は異常を認めな かった. 腹部単純 X 線写真で第 5 腰椎横突起骨折を認

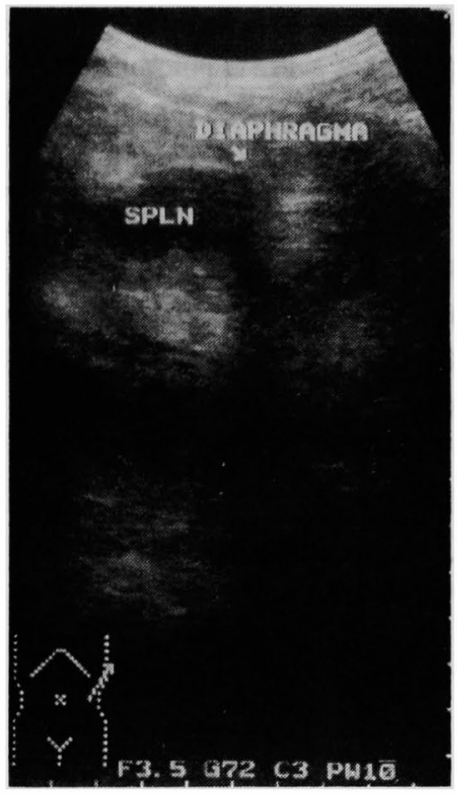

Fig. 1a We finded the diaphragma at the normal position over the spleen.

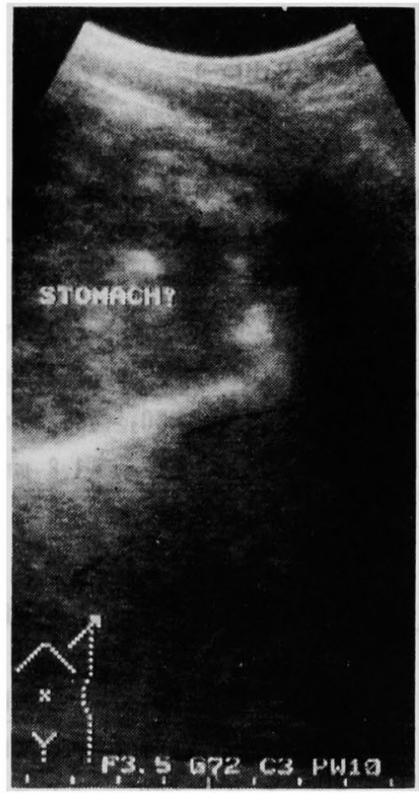

Fig. 1b There was a stomach over the diaphragma. And it bordered on the lung.
めた。

胸部 $\mathbf{X}$ 線写真所見：気胸はなく, 左横隔膜の挙上を 認めた。

超音波検査所見：Fig. 1a では脾蔵の上に正常位置 の横隔膜を認めた。プローブを走査すると Fig. 1bの ごとく横隔膜の上部に胃と思われる構造物を認め, そ れが肺に接している像が得られた。

CT 所見：Fig. 2a では, 本来左肺下葉があるべき部 位に大きな不整な内部 density を有する構造物を認め た. ガストログラフィン飲用後の Fig. 2b では内部に high density area が出現した. また, CT 後の胸部単 純 X 線写真では胃管の走行より胃の胸腔内への脱出 が認められた（Fig. 3)。

以上より胃を脱出臓器とする左の外傷性横隔膜へル ニアと診断し緊急手術を施行した。

手術所見：上腹部正中切開で開腹すると，左横隔膜 ほぼ中央に約 $10 \mathrm{~cm}$ の損傷があり胃と大網が胸腔内に 脱出していた。他の腹腔内葴器には異常を認めなかっ た。脱出臓器を腹腔内に戻し横隔膜を縫合閉鎖, 胸腔
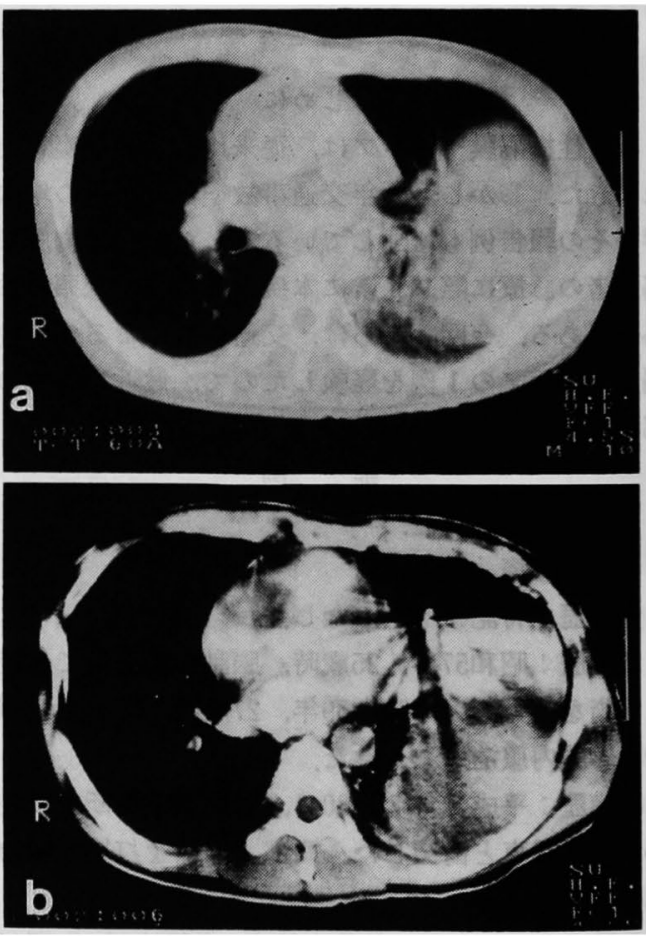

Fig. 2a We can see a large mass in the left lower lung, that have a irregular density.

Fig. 2b After drinking gastrografin, it appeared a high density area in the mass. 


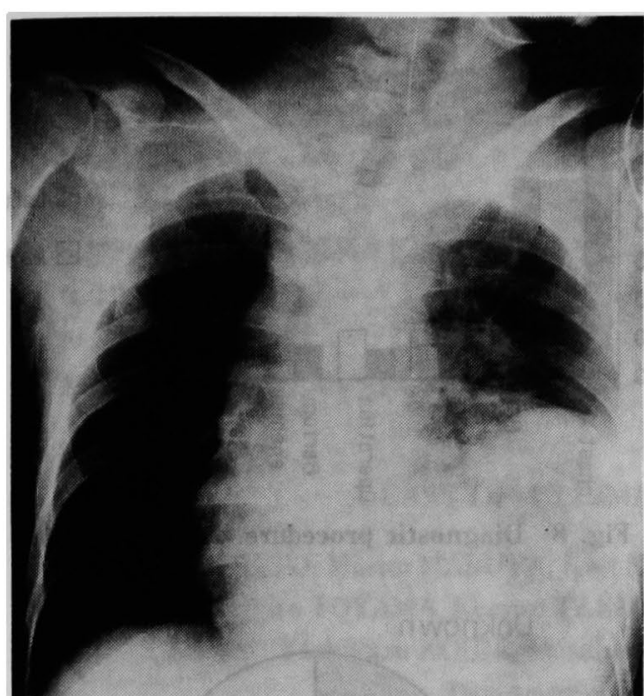

Fig. 3 Chest X-P revealed a stomach gas shadow in the left lung field.

ト゚レーンを挿入して手術を終了した。

術後経過は良好で第39病日目に軽快退院した。

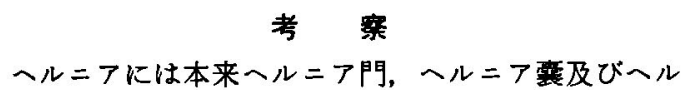
ニア内容が必要であるが, 外傷性横隔膜へルニフの多 くはールニフ震を有さない腹腔内葴器の胸腔内への脱 出である．その正確な発生頻度を知ることは困難であ るか，外傷患者の約 $1 \%$ にみられる5 といわれる。

今回著者らは，1981年 1 月より1990年11月までの10 年間の本邦報告267例を集計し，飯塚ら ${ }^{11}$, 児玉ら ${ }^{21}$, 浜 田ら ${ }^{3)}$ ，笠原ら"呠邦における1980年までの報告と比 較検討した。

性別と年龄：男女比は4.7：1 と男性に多く, 年齢別 では30歳代，40歳代に多かった，従来の報告では20歳 代に最も多く，ともに活動的な年代の男性に高頻度に 認められた（Fig. 4).

発生部位：左：右=2.8：1 と左に高頻度に欢られ た(Fig. 5)。これは右横隔膜は肝葴により保護されて いること，発生学上横隔膜の組織撚合が最後に完成す る左後外側が生理的脆弱部となることが原因と考古ら れている6)，笠原ら"の420例の報告では左：右は約 6.6：1 と左側例が著明に多かったが,今回の集計では 2.8：1 と左側例の比率が低下し, 右側例の增加傾向を 示した。これは近年における外傷の多様化および規模 の増大に関係すると考えられた。

受傷機転：鈍的外力による間接型が鋭的外力による

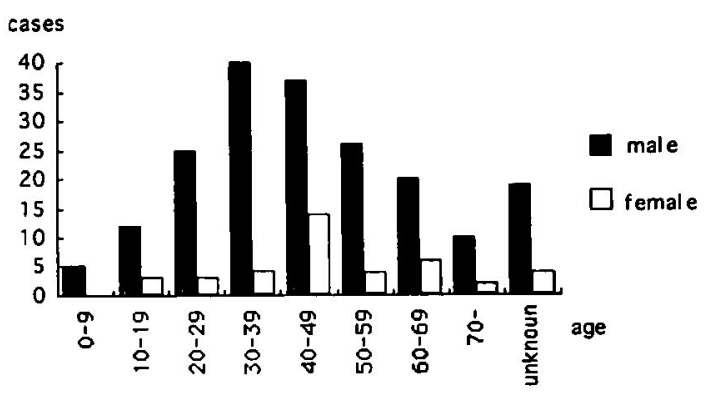

Fig. 4 Age and sex of the traumatic diaphragmatic hernia. 1981. 1 1990. 11

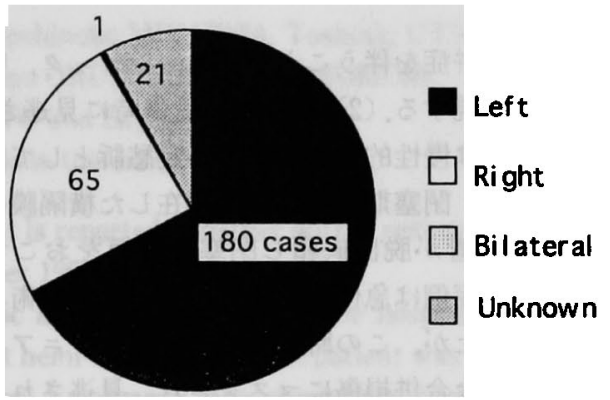

Fig. 5 Location of the traumatic diaphragmatic hernia. 1981. $1 \sim 1990.11$

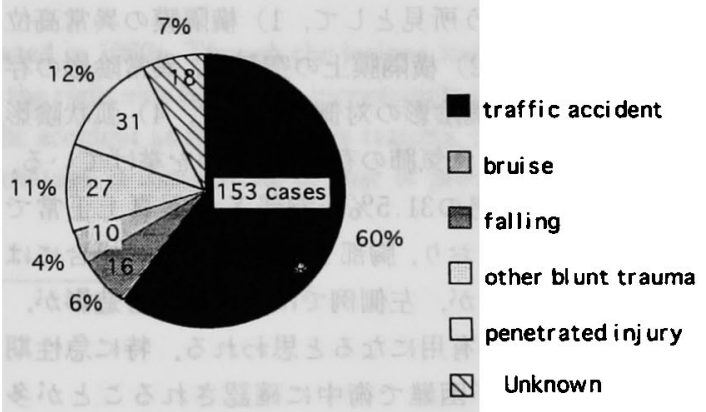

Fig. 6 Causes of the traumatic diaphragmatic hernia. 1981. 1 1990. 11

直接型に比して7：1と多く，特に交通事故によるも のの割合が受傷機転全体の約 $60 \%$ を占め著しく多かっ たが(Fig. 6)，従来の報告では36.4\%"1 $-50.8 \%{ }^{2)}$ と比 較的少なかった。

脱出㔉器：胃, 結腸, 大網の順に多く(Fig. 7), 右 側例では肝缄の脱出を多く認めた。ただし右側例でも 肝臓以外の葴器のみが脱出した例 (Peck III 型》) むあ り，診断に際しては，慎重を要すると考えられた。

臨床経過分類：Carter ら ${ }^{8)}$ は本疾患を臨床経過上り 次の 3 期に分類している，（1）急性期：受偒直後の時 


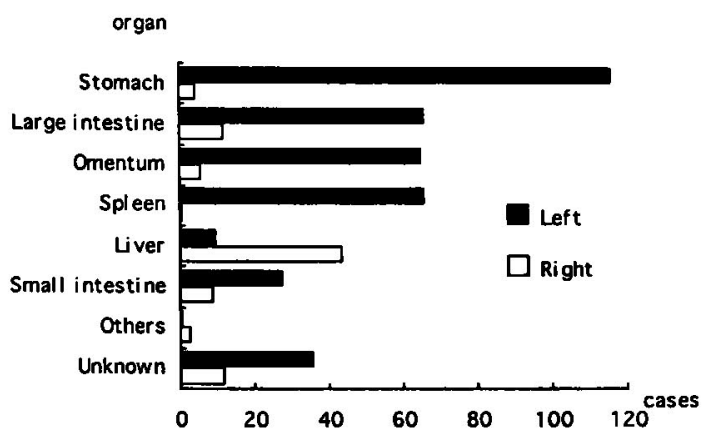

Fig. 7 Escaped organ of the traumatic di aphragmatic hernia. 1981. $1 \sim 1990.11$

期で重篤な合併症を伴らことが多く、ショック，呼吸 困難などが出現する.（2）慢性期：受傷時に見逃され， 無症状あるいは慢性的な胸腹部の不定愁訴として経過 する時期.（3）閉塞期：受傷時に存在した横隔膜の損 傷部より消化管が脱出嵌頓し閉塞や絞拒をおこす時 期. 著者らの症例は急性期に発見でき，緊急手術を施 行し救命しえたか，この時期では横隔膜へルニフ自体 の症状は重篤な合併損傷にマスクされ，見逃されるこ とも少なくはない。

術前診断：胸部単純 X 線写真が最も重要で Carter ら8)は本疾患を疑う所見として，1）横隔膜の異常高位 を示す弧状陰影，2）横隔膜上の空気像, 異常陰影の存 在,3）心缄，䋎隔陰影の対側への偏位，4）弧状陰影 に隣接した肺野の無気肺の存在,の4つを挙げている. Oliveira ${ }^{9 !}$ は本疾患の $31.5 \%$ が胸部 X 線写真上正常で あったと報告しており，胸部 X 線写真正常の場合には 脱出荿器にもよるか，左側例では上部消化管造影が, 右側例ではCT が有用になると思われる．特に急性期 例では術前診断が困難で術中に確認されることが多 く，今回の集計でも約 $16 \% か ゙$ 手術時に診断されており， 右側例ほど術中診断の占める率が高い傾向を認めた (Fig. 8).

治療：診断がつき次第，患者の状態がゆるすかぎり 手術を施行するのが原則である。手術のフブローチは 急性期には腹腔内缄器損傷が合併する可能性が高いの で開腹法を，慢性期には脱出臓器が胸腔内で瘾着して いることが多いため開胸法を選択するのが原則であ る.たたし，急性期でも右側例では視野を得るために 開胸操作が必要になると考えられる。横隔膜の閉鎖に は，一般的に非吸収性の繾合系で結節縫合あるいは マットレス縫合を行う，直接縫合が不可能な場合，縫 合部が脆弱な場合にはダクロン®等の人工膜を用いる

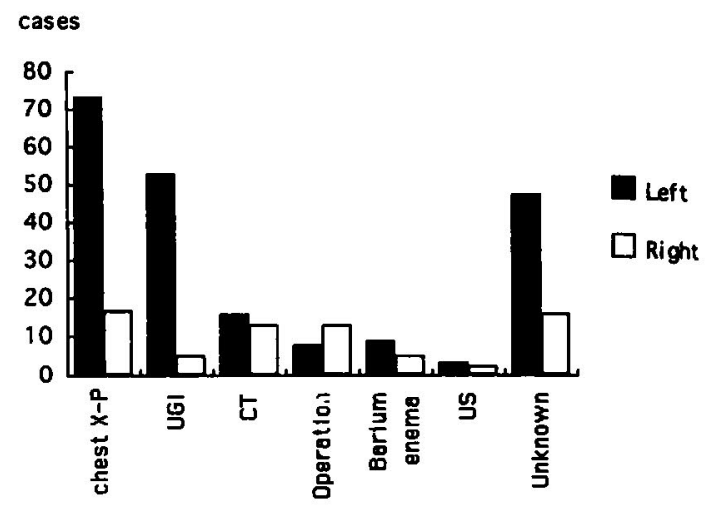

Fig. 8 Diagnostic procedure. 1981.1 1990. 11

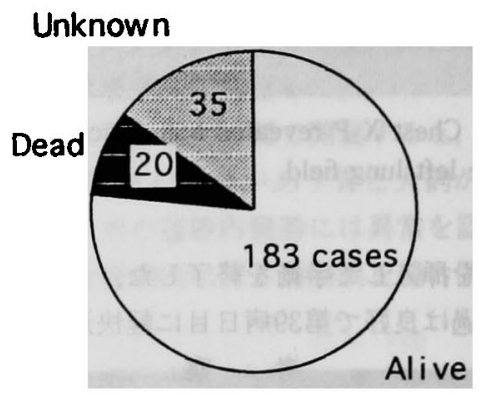

Fig. 9 Prognosis of the traumatic diaphrag. matic hernia. 1981. $1 \sim 1990.11$

ことがある.

予後：一般に良好であるが，合併損傷により大きく 左右される.今回の集計では予後の記載のあきらかな 203例中20例 (9.8\%) が死亡例であった（Fig. 9).こ れは従来の報告とほば同じ割合であった。

$$
\text { 結語 }
$$

交通事故による外傷性左横隔膜へルニフの1例を释 験したので，1981年 1 月から1990年11月をでの本邦報 告267例の集計を行い, 本邦例の1980年までの報告と比 較し若干の文献的考察を加え報告した。

本文の要旨は第232回東海外科学会例会（1990年 2 月11 日, 名古屋市)において発表した。

\section{文献}

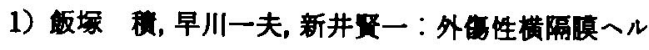
$=+$. 臨外 $11: 475-483,1956$

2）児玉長直，齐藤一夫，安藤 博他：胃穿孔を起した

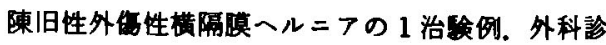
療 $15: 1249-1253,1973$

3）捠田節雄，渡辺千之，山岡郁雄他：校扼性イレゥス 
を来たした外传性横隔膜へルニフの1治験例，日 臨外医会誌 $38: 313-318,1977$

4）笠原 洋, 田中茂, 西野幹夫他：食道裂孔へル フに外儌性横隔膜ヘルニアを合併した 1 例。外科 診療 $23: 484-485,1981$

5）浅井康文, 宮下秀隆, 高橋延勝他：多発外伤をとる なった外侮性横隔膜へルニフの検討. 外科治療 $20: 1011-1015,1978$

6）堀田 稔，三浦則正，大野昭二他：外你性横隔膜人
ルニフの 1 例. 太田病年報 $24: 113-116,1989$

7) Peck WA: Right-side diaphragmatic liver hernia following trauma. AJR 78:99-108, 1957

8) Carter BN, Ginseffi J, Felson B, et al: Traumatic diaphragmatic hernia. Am J Roentgenol $\operatorname{Rad} 65: 56-72,1951$

9) De Oliveira F, Oliveira FJ, Queiros A: Traumatic diaphregmatic hernia. A report of 19 cases. Canad J Surg 25 : 658-661, 1982

\title{
A CASE OF TRAUMATIC DIAPHRAGMATIC HERNIA
}

\author{
Harunobu SATO, Morito MARUTA, Jyoji KUROMIZU, Yoshinobu MIYAJIMA, Toshiaki UTSUMI, \\ Kunihiro TOYAMA, Kenjiro TAKIZAWA, Yoshihiro OKUMURA, Koji MASUMORI, \\ Yoshikazu KOIDE, Masahisa MATSUMOTO and Sayoko MIZUTANI \\ Department of Surgery, Fujita Health University
}

A case of traumatic diaphragmatic hernia by traffic accident is reported, together with a review of 267 other cases reported in Japan in a period from January 1981 to November 1990.

A 31-year-old man who sustained blunt traumas by traffic accident was seen at the hospital because of lumbago. On admission, chest X-P revealed an elevation of the left hemi-diaphragma. The patient was diagnosed as traumatic left diaphragmatic hernia by US and CT examination. Emergency laparotomy was carried out. The escaped organs, stomach and omentum, were returned into the abdominal cavity and ruptured diaphragma was closed directly. Postoperative course was uneventful and the patient was discharged from the hospital 39 days after the surgery.

We compared our review with the previous papers reported in 1980s. Though the lesions had been said to be located commonly in the left side of the diaphragma, those in the right side have been increasingly reported in these years. There is an increasing tendency to be caused by traffic accident as the causative trauma. In this review of 203 causes. 20 death causes (9.8\%) are noted, and this percentage is comparable to that of previous reports by Kasahara. 